Clinical Medicine \& Research

\title{
Review
}

\section{Recent Advances in the Treatment of Graft-Versus-Host Disease}

\author{
Tsuyoshi Iwasaki, MD, PhD, Division of Rheumatology and Clinical Immunology, Department of Internal Medicine, \\ Hyogo College of Medicine, Nishinomiya, Hyogo, Japan
}

\begin{abstract}
Graft-versus-host disease (GVHD) is a lethal complication of allogeneic hematopoietic stem cell transplantation (HSCT) where immunocompetent donor T cells attack the genetically disparate host cells. The predominant symptoms of acute GVHD occur in the skin, liver, and intestine. Induction of acute GVHD can be divided into three phases: recipient conditioning, donor T cell activation, and effector cell-mediated GVHD. Chronic GVHD usually appears up to 100 days after HSCT and is characterized by symptoms similar to those observed for autoimmune disease. It is possible that chronic GVHD is the result of autoreactive T cells that escaped negative selection due to damage to the thymus from conditioning regimens, acute GVHD, and/or age related atrophy. Recent advances in the understanding of the basic mechanisms involved in GVHD pathophysiology have led to new strategies designed to block GVHD. This review focuses on recent developments in the treatment of GVHD, including insights gained from our own experimental studies.
\end{abstract}

\section{INTRODUCTION}

The widespread application of allogeneic hematopoietic stem cell transplantation (HSCT) for the treatment of hematological malignancies and other diseases is restricted by the poor availability of suitable donors. ${ }^{1-4}$ Significant barriers to successful major histocompatibility complex (MHC) mismatched HSCT include the increased risk of graft failure and the possible induction of severe and refractory acute and/or chronic graft-versus-host disease (GVHD). Even when the immune response is controlled through use of immunosuppressants, successfully engrafted recipients, free from active GVHD, often show delayed immune reconstitution and remain susceptible to fatal infection. In addition, suppression of the host immune response can lead to an increased risk of leukemic relapse. ${ }^{5-8}$ In this article, approaches to the prevention of GVHD are discussed with respect to three areas: (1) GVHD pathophysiology, (2) regimens in common clinical use, and (3) regimens under investigation.

\section{REPRINT REQUESTS:}

Tsuyoshi Iwasaki, MD, PhD

Division of Rheumatology and Clinical Immunology

Department of Internal Medicine

Hyogo College of Medicine

1-1 Mukogawa-cho

Nishinomiya, Hyogo 663-8501, Japan

Telephone: +81-798-45-6592

Fax: +81-798-45-6593

Email: tsuyo-i@hyo-med.ac.jp
KEYWORDS:

Graft vs host disease; FasL protein;

Graft vs leukemia effect;

Perforin; Hepatocyte growth factor;

Lupus erythematosus, systemic

GRANT SUPPORT:

Ministry of Education, Science and Culture of

Japan (No. 11671019, 14657120, and 15591071) 


\section{GVHD PATHOPHYSIOLOGY}

Acute GVHD is a pathological state that arises secondary to donor $\mathrm{T}$ cell engraftment and manifests as skin rash, diarrhea, jaundice, and wasting, such that the predominant symptoms are related to the skin, liver, and gastrointestinal (GI) tract. The majority of patients with grade III to IV acute GVHD die of their disease. ${ }^{9}$ Chronic GVHD usually begins at least 100 days after HSCT and can evolve from acute GVHD, follow the resolution of acute GVHD, or even start in patients without any history of acute GVHD. Chronic GVHD can mimic certain autoimmune diseases such as systemic lupus erythematosus, systemic sclerosis, and Sjogren's syndrome. ${ }^{10}$ Patients receiving peripheral blood stem cell transplantation have a higher incidence of chronic GVHD than those receiving standard HSCT. ${ }^{11}$ From the pathophysiological standpoint, the course of acute GVHD can be divided into three phases: (1) damage and cellular activation induced by the preconditioning treatment, (2) donor lymphocyte ( $\mathrm{T}$ cells) activation, and (3) cellular and inflammatory effectors (figure 1). ${ }^{12,13}$ Damage to the thymus may allow autoreactive $\mathrm{T}$ cells to escape negative selection, which then promotes T-helper 2 (Th2) responses and autoreactive $\mathrm{B}$ cell activation, leading to chronic GVHD (figure 2).

\section{PATHOPHYSIOLOGY OF ACUTE GVHD}

\section{Phase 1: Damage and cellular activation induced by} preconditioning

The first phase of acute GVHD occurs before the donor cells are even infused. Tissue damage caused by factors such as underlying disease, treatment of underlying disease, infection, and transplantation preconditioning can lead to cellular activation and release of inflammatory cytokines including tumor necrosis factor (TNF)- $\alpha$, interleukin (IL)-1, and IL-6. These cytokines induce the upregulation of host antigens and adhesion molecules allowing donor $\mathrm{T}$ cells to respond to host antigens. Damage to the GI mucosa induced by preconditioning can permit bacteria and bacterial endotoxins to enter the systemic circulation from the GI tract increasing the secretion of inflammatory cytokines from macrophages. ${ }^{14,15}$

\section{Phase 2: Activation of donor lymphocytes (T cells)}

Donor $\mathrm{T}$ cell activation constitutes the second phase of acute GVHD. Donor T cells recognize host antigen presenting cells (APC) and differentiate into T-helper 1 (Th1) cells that secrete Interferon (IFN)- $\gamma$ and IL-2. ${ }^{16,17}$

\section{Phase 3: Cellular and inflammatory effectors}

In the third phase, target cells are injured. Th1 cells that underwent differentiation during phase 2 induce cytotoxic $\mathrm{T}$ cell lymphocytes (CTL), and activate natural killer (NK) cells. These cells then attack various host target cells via Fas and perforin pathways. Th1 cells can also prime macrophages leading to increased production of inflammatory cytokines, such as TNF- $\alpha$, IL-1, and nitric oxide (NO), in response to stimulation by endotoxins that enter the systemic circulation from the GI tract. These

\section{Pathophysiology of Acute GVHD}

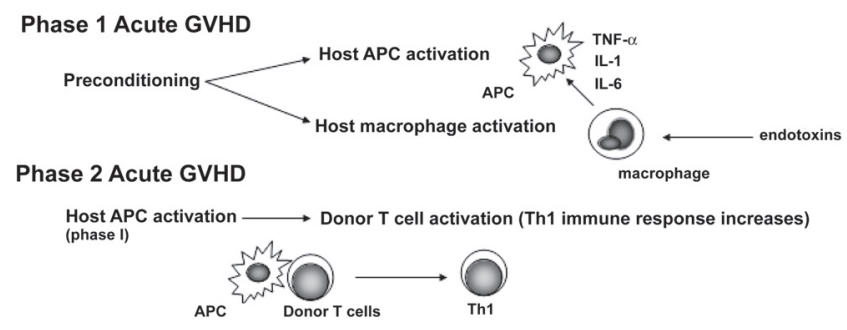

Phase 3 Acute GVHD

Host macrophage activation $\longrightarrow$ Inflammatory cytokine production increases

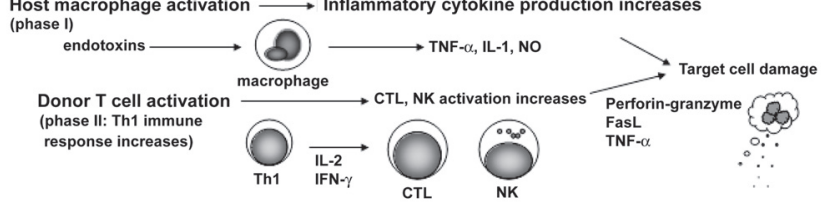

Figure 1. The pathophysiology of acute GVHD. Preconditioning, including irradiation and chemotherapy, leads to injury of host tissues, and the activation of host APC and macrophages. Host tissue injury involving the intestinal mucosa allows translocation of endotoxins from the intestinal lumen into the systemic circulation stimulating the secretion of TNF- $\alpha$, IL-1, and IL- 6 by macrophages. These cytokines increase the expression of $\mathrm{MHC}$ antigens and adhesion molecules on host APC enhancing the recognition of $\mathrm{MHC}$ antigens by mature donor T cells (phase 1). After recognition of $\mathrm{MHC}$ antigens on host APCs, donor T cells are activated and differentiate into Th1 cells. Th1 cells secrete IL-2 and IFN- $\gamma$ further expanding CTL and NK cell populations (phase 2). CTL and NK cells, expanded in phase 2, damage host tissues by perforin-granzyme and Fas-FasL pathways, and TNF- $\alpha$. Macrophages activated in phase 1 are further activated by endotoxins translocated from damaged Gl lumen leading to a cytokine storm characteristic of acute GVHD (phase 3). APC, antigen presenting cell; CTL, cytotoxic T cell lymphocytes; FasL, Fas ligand; IFN, interferon; NK, natural killer; Th1, type 1 helper; TNF, tumor necrosis factor.

cytotoxic molecules directly attack various host tissues and underlie the clinical manifestations of acute GVHD. ${ }^{14,18}$

\section{PATHOPHYSIOLOGY OF CHRONIC GVHD}

A murine model of chronic GVHD can be induced by the injection of DBA/2 $\left(\mathrm{H}-2^{\mathrm{d}}\right)$ spleen cells into immunocompetent (C57BL/6 x DBA/2) F1 (H-2 $\left.{ }^{\mathrm{b} / \mathrm{d}}\right)$ mice. These mice then show features of a lupus-like disease with renal involvement including autoantibody formation and polyclonal B cell activation. In this model, the small numbers of donor CD8+ CTL precursors lead to Th2 activation by donor CD4+ $\mathrm{T}$ cells and impaired elimination of autoreactive host B cells. ${ }^{19}$ This murine model is not relevant for human chronic GVHD because, in humans, host B cells do not survive after HSCT and glomerulonephritis is a very unusual manifestation of chronic GVHD. However, this model has demonstrated two key elements in the mechanisms of human chronic GVHD. The first is that the disease pathophysiology in chronic GVHD is dependent 


\section{Pathophysiology of Chronic GVHD}

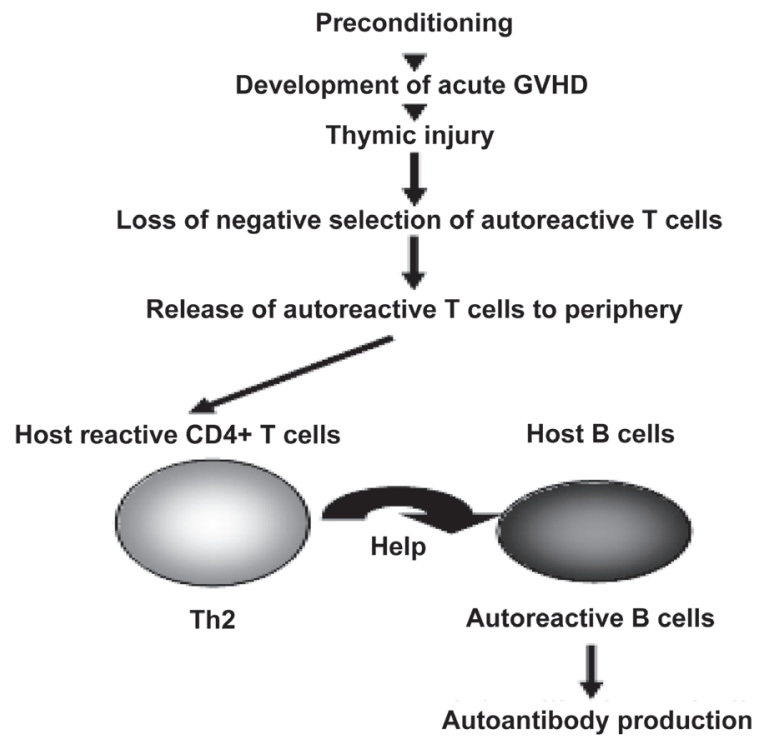

Figure 2. The pathophysiology of chronic GVHD. Chronic GVHD may be the result of autoreactive T cells that escape negative selection in the thymus that is damaged by preconditioning or acute GVHD. The Th2 immune response of donor CD4+ $\mathrm{T}$ cells released from negative selection provide help to host B cells to synthesize autoantibodies.

upon the continuous presence of host-reactive donor $\mathrm{T}$ cells. The second insight from this model is the predominant Th2 activation in chronic GVHD. The thymus plays a critical role in the prevention of autoimmunity by eliminating autoreactive $\mathrm{T}$ cells. It has been suggested that chronic GVHD is caused by autoreactive T cells that escape negative selection in the thymus damaged by conditioning regimens, acute GVHD, and/or age-related atrophy. ${ }^{20}$ Murine and human studies of chronic GVHD have revealed involution of the thymic epithelium, lymphocyte depletion, disappearance of Hassal corpuscles, and loss of thymic function. ${ }^{21,22}$ Taken together, these findings suggest that chronic GVHD, which can occur months after the allogeneic HSCT, may be due to the Th2 immune response of donor CD4+ T cells that escaped the negative thymic selection and which then go on to recognize MHC antigens on host APC. These donor CD4+ T cells then provide help to host B cells to synthesize autoantibodies against various host tissue antigens (figure 2).

\section{REGIMENS IN COMMON CLINICAL USE}

Immunosuppressive agents that disrupt phase 2 of the GVHD cascade are in wide use. Some of the commonly used immunosuppressive agents, including cyclosporin, corticosteroids, tacrolimus, mycophenolate mofetil, and $\mathrm{T}$ cell depletion by Campath-1, are discussed.

\section{Cyclosporin}

Cyclosporin is a metabolite obtained from two species of fungi isolated from soil samples collected in the Hardanger highlands of Norway in 1970.23,24 It is a cyclic peptide consisting of 11 amino acid residues and its immunosuppressive mechanism is based on its activity against calcineurin. ${ }^{25}$ Cyclosporin forms a complex with cyclophilin which then inhibits the dephosphorylase activity of activated calcineurin. Without the dephosphorylation activity of calcineurin, cytoplasmic nuclear factor of activated T cells (NFAT) is not translocated into the nucleus and does not result in suppression of IL-2 mRNA transcription and the blockade of expression of many other cytokines. ${ }^{26-28}$ Short course methotrexate plus cyclosporine has become the standard regimen for GVHD prophylaxis. ${ }^{29}$

\section{Corticosteroids}

While the immunosuppressive effects of corticosteroids have not yet been fully elucidated, their actions appear to be mediated by intracellular glucocorticoid receptors (GR). 30 Steroid-GR complexes form dimers after migration into the nucleus, which are then thought to act as transcription factors that recognize GR binding motifs at target gene promoters, blocking the expression of various cytokines and enzymes. ${ }^{31,32}$ In addition, corticosteroids also appear to suppress transcription factors, such as activation protein-1 (Jun/Fos complex) and nuclear factor-kappaB, thereby inhibiting the expression of molecules dependent on these factors including cytokines and various enzymes and receptors. ${ }^{33-35}$ While it was reported by Chao et al. ${ }^{36}$ in 1992 that the three-drug combination of cyclosporine, methotrexate, and methylprednisolone resulted in GVHD prophylaxis, it was later found that the addition of methylprednisolone increased the risk of bacterial and fungal infection. ${ }^{37}$

\section{Tacrolimus}

Tacrolimus is a metabolite isolated from Actinomyces spp 38 and, like cyclosporine, forms a complex with a specific protein (FK506-binding protein [FKBP]) that then binds to calcineurin and inhibits its dephosphorylase activity. ${ }^{25}$ This prevents the migration of the IL-2 gene transcription factor NFAT into the nucleus, therefore blocking subsequent IL-2 biosynthesis. ${ }^{28}$ At some centers, tacrolimus has replaced cyclosporine based on the results of two phase III clinical trials that showed a slight decrease in grade II to IV acute GVHD after treatment with tacrolimus plus methotrexate compared with cyclosporine plus methotrexate. However, there was no difference between the treatment in terms of overall disease-free survival. ${ }^{39,40}$ A controlled clinical trial by Hiraoka et al. ${ }^{41}$ showed that the incidence of grade II to IV acute GVHD within 100 days of transplantation was significantly lower among patients that received tacrolimus compared to patients that received cyclosporine. However, the study also showed a significantly higher recurrence rate following transplantation from HLA-matched sibling donors in patients treated with tacrolimus. Animal data from our institute indicated that tacrolimus significantly inhibited donor CTL activity against the leukemic cell line P815 and increased leukemic death in mice injected with P815 cells after HSCT. ${ }^{42}$ Consequently, the GVHD prevention regimen prescribed should take into account both GVHD prophylaxis and the graft-versus-leukemia (GVL) effect. 


\section{Mycophenolate mofetil}

Mycophenolate mofetil (MMF), also known as RS-61443, is an ester of mycophenolic acid (MPA) that inhibits the de novo synthesis of guanine nucleotides. ${ }^{43}$ Following oral administration, MMF is hydrolyzed by esterase in the intestine and blood to release MPA. MPA exerts a more potent cytostatic effect on lymphocytes than on other cell types, such that its effect on lymphocytes is the principal mechanism of its immunosuppressive activity. ${ }^{44} \mathrm{MMF}$ in combination with cyclosporine and prednisolone is a useful treatment against GVHD, ${ }^{45}$ while cyclosporine plus MMF has been shown to be beneficial in GVHD prophylaxis for nonmyeloablative transplants. ${ }^{46}$

\section{T cell depletion}

Although T cell depletion is effective in the prevention of GVHD, the survival benefit of T cell depletion is less than expected due to increased rejection rate, leukemia relapse, and incidence of infection due to delayed recovery of immunity. ${ }^{47-50}$ The rat antibody Campath-1 recognizes the human lymphocyte antigen CD52 and effectively purges $\mathrm{T}$ cells in vitro by cell lysis, but leads to higher relapse rates due to ablation of the GVL effect. ${ }^{49}$ However, in vitro $\mathrm{T}$ cell depletion with Campath-1 followed by in vivo application of Campath-1 has shown promising results. The incidence of acute and chronic GVHD was $4 \%$ and $3 \%$, respectively, in a Campath-1-treated group compared with $35 \%$ and $36 \%$, respectively, in a cyclosporine plus methotrexate-treated group. An equal risk of relapse was observed between the groups. ${ }^{51}$ Campath-1 has also been used in nonmyeloablative HSCT with promising results. ${ }^{52}$

\section{REGIMENS UNDER INVESTIGATION FOR ACUTE GVHD}

\section{Blockage of the phase 1 GVHD cascade}

The GI tract is not only a major target organ of GVHD, but is also a critical amplifier of systemic GVHD severity. Damage to the intestinal mucosa by conditioning regimens allows the translocation of endotoxins from the intestinal lumen into the circulation stimulating inflammatory cytokine production by gut-associated lymphocytes and macrophages. These mechanisms amplify local tissue injury and further promote inflammatory responses in GVHD target organs (figure 1). Thus, it would be of benefit to interrupt the processes involved in GI tract damage. Reduction in doses of chemotherapy and total body irradiation used for preconditioning can reduce GVHD, as demonstrated in animal models. ${ }^{14,18}$ The use of nonmyeloablative conditioning should also reduce GI tract damage after allogeneic HSCT. The initial focus of allogeneic HSCT was for preventing death from marrow failure after treatment with myeloablative doses of irradiation and chemotherapy to eliminate the leukemia. Today, the emphasis has shifted to eradication of the leukemia using alloimmune effector cells, with radiation and chemotherapy doses limited to allowing donor stem cell engraftment, leading to reduced toxicity from HSCT conditioning. Several multicenter surveys have demonstrated that the GVL effect of nonmyeloablative conditioning and donor lymphocyte infusion is most effective in chronic myelogenous leukemia, whereas the benefit is less pronounced for acute leukemia and myeloma. ${ }^{53}$ Another strategy to reduce GI tract damage is to reduce the load of gram-negative bacteria in the GI tract. While this is already current practice at a number of centers, the effect of gut decontamination on reduced GVHD severity is only partial. ${ }^{54-56}$ An alternative to preventing GI tract damage involves strengthening the GI mucosal barrier prior to preconditioning. Three growth factors, IL-11, keratinocyte growth factor, and hepatocyte growth factor, have recently been shown to prevent GI tract damage and subsequent inflammatory responses induced by endotoxins in the GI tract lumen in murine models. ${ }^{57-62}$ Therapy using these growth factors preserved donor $\mathrm{T}$ cell responses to host antigens and significantly improved leukemia-free survival and may, therefore, form the basis of novel approaches to separate the GVL effect from GVHD. ${ }^{60-62}$ However, the results of a phase I/II double-blind, controlled clinical trial of recombinant IL-11 in the prevention of acute GVHD were not satisfactory. Patients who received IL-11 exhibited severe fluid retention and early mortality making it impossible to determine whether IL-11 reduced the rate of acute GVHD. 63

\section{Blockade of the phase 2 GVHD cascade}

Activation of IL-2 production and induction of IL-2 receptor expression by $\mathrm{T}$ cells requires two signals: (1) $\mathrm{T}$ cell receptor engagement, and (2) a costimulatory signal via CD28. 64,65 Therefore, it may be possible to prevent GVHD by inhibiting $\mathrm{T}$ cell activation through blocking $\mathrm{T}$ cell receptor signaling and/or CD28-mediated costimulation. Two studies that used an anti-IL-2 receptor monoclonal antibody (Daclizumab) to treat patients with steroid-resistant GVHD showed complete response rates of $29 \%$ and $47 \%$. ${ }^{66}$ However, a randomized study of corticosteroids with or without Daclizumab for the initial treatment of acute GVHD found a significantly worse 100-day survival in patients who received corticosteroids plus Daclizumab compared to patients who received corticosteroids only (77\% vs. 94\%, respectively) due to both increased relapse and GVHD-related mortality. ${ }^{67}$ CTL-associated antigen-4 binds more strongly to $\mathrm{CD} 80 / \mathrm{CD} 86$ expressed on APCs than CD28. The chimeric CTL-associated antigen-4-Ig protein binds to CD80/CD86 with high affinity and blocks T cell CD28 binding, preventing graft rejection and GVHD in experimental models. ${ }^{68,69}$ Guinan et al. ${ }^{70}$ studied 12 patients transplanted with MHC-mismatched bone marrow that had been cultured with irradiated recipient cells and CTL-associated antigen-4-Ig before infusion to induce specific anergy to recipient antigens. While patients did exhibit intestinal GVHD, none of the patients died of GVHD or experienced skin or liver GVHD. ${ }^{70}$

\section{Blockade of the phase 3 GVHD cascade}

The Fas receptor-Fas ligand (Fas-FasL) and perforin-granzyme pathways are the classic effector mechanisms used by CTLs 
and NK cells to lyse target cells. ${ }^{71,72}$ Several murine studies have analyzed the role of the Fas-FasL pathway in the development of GVHD by the in vivo administration of neutralizing anti-FasL antibodies. ${ }^{73,74}$ Although some differences between the studies were observed, the studies indicated that the Fas-FasL pathway played an important role in the development of systemic GVHD. In contrast, few studies have shown evidence for perforin-granzyme pathway involvement in systemic GVHD. Several strategies that target cytolytic pathways have been considered. For example, the Fas-FasL pathway could be inhibited with decoy receptors such as DCR3 and Fas-IgFc, metalloproteinase inhibitors, or neutralizing humanized anti-FasL antibodies. The role of TNF- $\alpha$ in GVHD pathogenesis has been well documented with involvement of TNF- $\alpha$ in intestinal GVHD shown in both mouse and human studies. ${ }^{74-76}$ Infliximab is a genetically constructed IgG1 murine-human chimeric monoclonal antibody that binds to both the soluble and the membrane-bound forms of TNF- $\alpha$, and not only blocks interaction with TNF- $\alpha$ receptors, but also causes the lysis of TNF- $\alpha$-producing cells. Treatment with infliximab has been reported to be effective against steroid-resistant severe acute GVHD, particularly in the case with GI tract involvement. However, infliximab administration has been associated with an increased risk of fungal infections. ${ }^{77-80}$

\section{TREATMENT AND PREVENTION OF CHRONIC GVHD}

Corticosteroids are the most widely used treatment for chronic GVHD, ${ }^{81}$ with only approximately $30 \%$ of patients who require secondary systemic treatment receiving medication other than corticosteroids. Although a variety of agents have been tested, secondary treatments for chronic GVHD have been shown to be less successful than primary treatment. 82,83 Recently, salvage therapies for refractory chronic GVHD have produced promising preliminary results. A combination of MMF and tacrolimus showed an objective response in $46 \%$ of patients with refractory chronic GVHD. ${ }^{84}$

Hydroxychloroquine is a 4-aminoquinoline antimalarial drug used for the treatment of autoimmune diseases. A Phase II clinical trial of hydroxychloroquine for steroid-resistant chronic GVHD showed a 53\% response rate. ${ }^{85}$ Pentostatin demonstrated considerable symptom response when used to treat refractory chronic GVHD in a small series of pediatric patients. ${ }^{86}$ Extracorporeal photochemotherapy has been shown to be effective in the treatment of cutaneous $\mathrm{T}$ cell lymphoma and some autoimmune diseases. Several studies found improvement in the skin and visceral manifestations of chronic GVHD. ${ }^{87}$ However, improved understanding of the pathophysiology of chronic GVHD is needed to develop more effective treatment approaches. It has been suggested that chronic GVHD is the result of autoreactive T cells that escaped negative selection due to damage to the thymus by conditioning regimens, acute GVHD, and/or age-related atrophy. ${ }^{20}$
We recently demonstrated that transfection of the hepatocyte growth factor gene in vivo prevented the development of chronic GVHD in a murine model. ${ }^{62}$ Hepatocyte growth factor (HGF) was originally identified and cloned as a potent hepatocyte mitogen. ${ }^{88,89}$ It has also been shown to have mitogenic, motogeneic, and morphogenic effects on various non-hepatic epithelial tissues, particularly the kidneys, lungs, and intestine. ${ }^{90-92}$ Intravenous injection of recombinant HGF enhanced liver and kidney regeneration in mice, prevented acute renal failure, and suppressed the onset of dimethylnitrosamine-induced liver cirrhosis suggesting HGF appears to play an important role in tissue repair. ${ }^{90,93}$ Serum HGF levels were found to be significantly increased in patients with acute GVHD, which suggested that HGF was produced to counteract the tissue damage caused by acute GVHD. ${ }^{94}$ Therefore, we attempted to treat a murine model of acute GVHD with HGF.

Repeated transfections of the human HGF gene into the skeletal muscle of GVHD mice strongly inhibited acute GVHD by limiting GI injury and the subsequent endotoxin-mediated inflammatory cascade. ${ }^{59} \mathrm{HGF}$ also protected against thymic injury caused by acute GVHD, therefore preventing the generation of host-reactive T cells and the development of chronic GVHD. ${ }^{62}$ Chronic GVHD is characterized by the stimulation of donor $\mathrm{T}$ cells toward the Th2 phenotype.

Via et al. ${ }^{95}$ observed an augmented donor anti-host CTL response in IL-12-treated mice with chronic GVHD, and conversion to acute GVHD in parent-to-F1 mouse experiments. Okamoto et al. ${ }^{96}$ examined the effect of murine recombinant IL-18 treatment and demonstrated the prevention of chronic GVHD. IL-18 treatment also augmented donor anti-host CTL, but did not lead to acute GVHD as observed with IL-12 suggesting IL-18 may be useful in novel therapies for patients after HSCT. ${ }^{96}$ We also examined the effect of HGF on Th2 immune responses using the parent-to-F1 murine model. HGF treatment effectively prevented the proteinuria and histological changes of glomerulonephritis.

Liver sections from control GVHD mice showed prominent primary biliary cirrhosis-like changes, indicated by lymphocyte infiltration into the periportal area of the liver. HGF-treated GVHD mice showed reduced histological changes of primary biliary cirrhosis. HGF-treated mice also showed down-regulation of Th2 cytokine mRNA expression in the spleen, liver, and kidneys. HGF may therefore represent a novel strategy for the control of Th2 immune responses in chronic GVHD.

\section{FUTURE DIRECTIONS}

A successful outcome of HSCT involves engraftment, prevention of GVHD, eradication of leukemia, and immune reconstitution. GVHD and GVL are closely linked; the severity of GVHD is inversely correlated with the probability of a relapse after allogeneic HSCT. ${ }^{97}$ At present, 
several strategies are being developed to separate GVHD from GVL activity. Most efforts are being focused on the identification of GVHD-specific and tumor-specific antigens, and the application of T cells that respond to tumor antigens for adoptive cell therapy. ${ }^{70,98-100}$ Neutralization of inflammatory cytokines with antibodies ${ }^{18,74-76}$ or blocking endotoxin translocation from the GI tract lumen into the systemic circulation to decrease inflammatory cytokine responses ${ }^{60-62}$ also appears to be useful for the separation of GVHD from GVL activity (table 1). However, effective control of GVHD will most likely involve the blocking of several steps in GVHD pathogenesis using several approaches in concert.

New methods of reducing toxicity while retaining the anti-tumor potential of HSCT, including donor lymphocyte infusion and nonmyeloablative conditioning, have led to a significant decrease in the occurrence of acute GVHD. Unfortunately, along with the decline of acute GVHD, chronic GVHD has begun to emerge as a major complication of HSCT. ${ }^{101}$ Chronic GVHD occurs in approximately $60 \%$ of patients who survive for more than 100 days after receiving an allogeneic marrow or peripheral blood stem cell transplant without $\mathrm{T}$ cell depletion of the graft. It represents a major cause of morbidity and mortality following allogeneic HSCT. It has been suggested that chronic GVHD is due to damage to the thymus from conditioning regimens, acute GVHD, and/or age related atrophy that allows autoreactive $\mathrm{T}$ cells to escape negative thymus selection. ${ }^{20}$ Chronic GVHD is also characterized by the stimulation of donor $\mathrm{T}$ cells toward the Th2 phenotype. Therefore, new strategies to block thymic injury using keratinocyte growth factor or HGF, as well as inhibiting Th2 activation by IL-18, may prove useful in the treatment of chronic GVHD. ${ }^{61,62,96}$

\section{CONCLUSIONS}

The mechanisms of GVHD have been progressively elucidated over recent years and new treatments have been developed using experimental models. However, both acute and chronic GVHD remain difficult to treat. Many clinical approaches to acute GVHD, such as treatment with immunosuppressants or ex vivo T cell depletion of the HSCT, reduce GVL activity. The most effective approach to treat acute GVHD is likely to be one that disrupts all three phases of the GVHD cascade synergistically. For example, a useful strategy might involve blocking GI tract damage by treatment with IL-11, keratinocyte growth factor, or HGF along with induction of specific anergy using a CTL-associated antigen-4 monoclonal antibody and neutralization of TNF- $\alpha$ using infliximab.

Chronic GVHD may be the result of autoreactive T cells that escaped negative selection due to the thymus being damaged by the conditioning regimen, acute GVHD, and/or age-related atrophy, and also involves increased Th2 immune responses. Therefore, blocking thymic injury using keratinocyte growth factor, HGF, or inhibition of Th2 activation by IL-18 may represent useful treatments for chronic GVHD. The various new treatment options currently being examined in animal models should improve the outlook for patients with acute or chronic GVHD.

\section{ACKNOWLEDGMENTS}

We thank Kaname Saheki, Takanori Kuroiwa, Yasuro Kataoka and Takehito Imado for performing our experiments.

\section{REFERENCES}

1. Prentice HG, Blacklock HA, Janossy G, Gilmore MJ, Price-Jones L, Tidman N, Trejdosiewicz LK, Skeggs DB, Panjwani D, Ball $\mathrm{S}$. Depletion of T lymphocytes in donor marrow prevents significant graft-versus-host disease in matched allogeneic leukaemic marrow transplant recipients. Lancet 1984;1:472-476.

2. Thomas ED, Storb R, Clift RA, Fefer A, Johnson L, Neiman PE, Lerner KG, Glucksberg H, Buckner CD. Bone-marrow transplantation (second of two parts). N Engl J Med 1975;292:895-902.

3. Deeg HJ, Storb R. Graft-versus-host disease: pathophysiological and clinical aspects. Annu Rev Med 1984;35:11-24.

4. Ferrara JL, Deeg HJ. Graft-versus-host disease. N Engl J Med 1991;324:667-674.

Table 1. Strategies to separate GVHD from GVL activity.

\begin{tabular}{ll}
\hline Strategy Reference &
\end{tabular}

Delayed infusion of donor leukocytes

Induction of specific anergy to alloantigens

Positive selection of donor cells with anti-leukemic activity

Introduction of a suicide gene into donor T cells

Neutralization of inflammatory cytokines

Blocking of endotoxin translocation from the gut lumen into the systemic circulation
53,101

70

98,99

100

$18,74-76$

$60-62$ 
5.Drobyski WR, Ash RC, Casper JT, McAuliffe T, Horowitz MM, Lawton C, Keever C, Baxter-Lowe LA, Camitta B, Garbrecht F. Effect of T-cell depletion as graft-versus-host disease prophylaxis on engraftment, relapse, and disease-free survival in unrelated marrow transplantation for chronic myelogenous leukemia. Blood 1994;83:1980-1987.

6. Young JW, Papadopoulos EB, Cunningham I, Castro-Malaspina H, Flomenberg N, Carabasi MH, Gulati SC, Brochstein JA, Heller G, Black P. T-cell-depleted allogeneic bone marrow transplantation in adults with acute nonlymphocytic leukemia in first remission. Blood 1992;79:3380-3387.

7. Pirsch JD, Maki DG. Infectious complications in adults with bone marrow transplantation and T-cell depletion of donor marrow. Increased susceptibility to fungal infections. Ann Intern Med 1986;104:619-631.

8. Marmont AM, Horowitz MM, Gale RP, Sobocinski K, Ash RC, van Bekkum DW, Champlin RE, Dicke KA, Goldman JM, Good RA. T-cell depletion of HLA-identical transplants in leukemia. Blood 1991;78:2120-2130.

9. Przepiorka D, Weisdorf D, Martin P, Klingemann HG, Beatty P, Hows J, Thomas ED. 1994 Consensus Conference on Acute GVHD Grading. Bone Marrow Transplant 1995;15:825-828.

10. Flowers ME, Kansu E, Sullivan KM. Pathophysiology and treatment of graft-versus-host disease. Hematol Oncol Clin North Am 1999;13:1091-1112.

11. Cutler C, Giri S, Jeyapalan S, Paniagua D, Viswanathan A, Antin JH. Acute and chronic graft-versus-host disease after allogeneic peripheral-blood stem-cell and bone marrow transplantation: a meta-analysis. J Clin Oncol 2001;19:3685-3691.

12. Ferrara JL, Levy R, Chao NJ. Pathophysiologic mechanisms of acute graft-vs.-host disease. Biol Blood Marrow Transplant 1999;5:347-356.

13. Hill GR, Ferrara JL. The primacy of the gastrointestinal tract as a target organ of acute graft-versus-host disease: rationale for the use of cytokine shields in allogeneic bone marrow transplantation. Blood 2000;95:2754-2759.

14. Hill GR, Crawford JM, Cooke KR, Brinson YS, Pan L, Ferrara JL. Total body irradiation and acute graft-versus-host disease: the role of gastrointestinal damage and inflammatory cytokines. Blood 1997;90:3204-3213.

15. Nash RA, Pepe MS, Storb R, Longton G, Pettinger M, Anasetti C, Appelbaum FR, Bowden RA, Deeg HJ, Doney K. Acute graft-versus-host disease: analysis of risk factors after allogeneic marrow transplantation and prophylaxis with cyclosporine and methotrexate. Blood 1992;80:1838-1845.

16. Shlomchik WD, Couzens MS, Tang CB, McNiff J, Robert ME, Liu J, Shlomchik MJ, Emerson SG. Prevention of graft versus host disease by inactivation of host antigen-presenting cells. Science 1999;285:412-415.

17. Teshima T, Ordemann R, Reddy P, Gagin S, Liu C, Cooke KR, Ferrara JL. Acute graft-versus-host disease does not require alloantigen expression on host epithelium. Nat Med 2002;8:575-581.

18. Hill GR, Teshima T, Gerbitz A, Pan L, Cooke KR, Brinson YS, Crawford JM, Ferrara JL. Differential roles of IL-1 and TNF-alpha on graft-versus-host disease and graft versus leukemia. J Clin Invest 1999;104:459-467.

19. Rus V, Svetic A, Nguyen P, Gause WC, Via CS. Kinetics of Th1 and Th2 cytokine production during the early course of acute and chronic murine graft-versus-host disease. Regulatory role of donor CD8+ T cells. J Immunol 1995;155:2396-2406.

20. Weinberg K, Blazar BR, Wagner JE, Agura E, Hill BJ, Smogorzewska M, Koup RA, Betts MR, Collins RH, Douek DC. Factors affecting thymic function after allogeneic hematopoietic stem cell transplantation. Blood 2001;97:1458-1466.

21. Atkinson K, Incefy GS, Storb R, Sullivan KM, Iwata T, Dardenne M, Ochs HD, Good RA, Thomas ED. Low serum thymic hormone levels in patients with chronic graft-versus-host disease. Blood 1982;59:1073-1077.
22. Seddik M, Seemayer TA, Lapp WS. T cell functional defect associated with thymid epithelial cell injury induced by a graft-versus-host reaction. Transplantation 1980;29:61-66.

23. Borel JF, Feurer C, Magnee C, Stahelin H. Effects of the new anti-lymphocytic peptide cyclosporin A in animals. Immunology 1977;32:1017-1025.

24. Borel JF, Feurer C, Gubler HU, Stahelin H. Biological effects of cyclosporin A: a new antilymphocytic agent. Agents Actions 1976;6:468-475.

25. Liu J, Farmer JD Jr, Lane WS, Friedman J, Weissman I, Schreiber SL. Calcineurin is a common target of cyclophilin-cyclosporin A and FKBP-FK506 complexes. Cell 1991;66:807-815.

26. Fruman DA, Klee CB, Bierer BE, Burakoff SJ. Calcineurin phosphatase activity in T lymphocytes is inhibited by FK 506 and cyclosporin A. Proc Natl Acad Sci U S A 1992;89: 3686-3690.

27. O’Keefe SJ, Tamura J, Kincaid RL, Tocci MJ, O'Neill EA. FK-506- and CsA-sensitive activation of the interleukin-2 promoter by calcineurin. Nature 1992;357:692-694.

28. Shibasaki F, Price ER, Milan D, McKeon F. Role of kinases and the phosphatase calcineurin in the nuclear shuttling of transcription factor NF-AT4. Nature 1996;382:370-373.

29. Storb R, Deeg HJ, Pepe M, Appelbaum F, Anasetti C, Beatty P, Bensinger W, Berenson R, Buckner CD, Clift R. Methotrexate and cyclosporine versus cyclosporine alone for prophylaxis of graft-versus-host disease in patients given HLA-identical marrow grafts for leukemia: long-term follow-up of a controlled trial. Blood 1989;73:1729-1734.

30. Evans RM. The steroid and thyroid hormone receptor superfamily. Science 1988;240:889-895.

31. Bamberger CM, Schulte HM, Chrousos GP. Molecular determinants of glucocorticoid receptor function and tissue sensitivity to glucocorticoids. Endocr Rev 1996;17:245-261.

32. Pratt WB, Toft DO. Steroid receptor interactions with heat shock protein and immunophilin chaperones. Endocr Rev 1997; 18:306-360.

33. Yang-Yen HF, Chambard JC, Sun YL, Smeal T, Schmidt TJ, Drouin J, Karin M. Transcriptional interference between c-Jun and the glucocorticoid receptor: mutual inhibition of DNA binding due to direct protein-protein interaction. Cell 1990;62:1205-1215.

34. Ray A, Prefontaine KE. Physical association and functional antagonism between the $\mathrm{p} 65$ subunit of transcription factor NF-kappaB and the glucocorticoid receptor. Proc Natl Acad Sci U S A 1994;91:752-756.

35. Heck S, Bender K, Kullmann M, Gottlicher M, Herrlich P, Cato AC. I kappaB alpha-independent downregulation of NF-kappaB activity by glucocorticoid receptor. EMBO J 1997;16:4698-4707.

36. Chao NJ, Schmidt GM, Niland JC, Amylon MD, Dagis AC, Long GD, Nademanee AP, Negrin RS, O’Donnell MR, Parker PM. Cyclosporine, methotrexate, and prednisone compared with cyclosporine and prednisone for prophylaxis of acute graft-versus-host disease. N Engl J Med 1993;329:1225-1230.

37. Sayer HG, Longton G, Bowden R, Pepe M, Storb R. Increased risk of infection in marrow transplant patients receiving methylprednisolone for graft-versus-host disease prevention. Blood 1994;84:1328-1332.

38. Kino T, Hatanaka H, Hashimoto M, Nishiyama M, Goto T, Okuhara M, Kohsaka M, Aoki H, Imanaka H. FK-506, a novel immunosuppressant isolated from a Streptomyces. I. Fermentation, isolation, and physico-chemical and biological characteristics. J Antibiot (Tokyo) 1987;40:1249-1255. 
39. Ratanatharathorn V, Nash RA, Przepiorka D, Devine SM, Klein JL, Weisdorf D, Fay JW, Nademanee A, Antin JH, Christiansen NP, van der Jagt R, Herzig RH, Litzow MR, Wolff SN, Longo WL, Petersen FB, Karanes C, Avalos B, Storb R, Buell DN, Maher RM, Fitzsimmons WE, Wingard JR. Phase III study comparing methotrexate and tacrolimus (prograf, FK506) with methotrexate and cyclosporine for graft-versus-host disease prophylaxis after HLA-identical sibling bone marrow transplantation. Blood 1998;92:2303-2314.

40. Nash RA, Antin JH, Karanes C, Fay JW, Avalos BR, Yeager AM, Przepiorka D, Davies S, Petersen FB, Bartels P, Buell D, Fitzsimmons W, Anasetti C, Storb R, Ratanatharathorn V. Phase 3 study comparing methotrexate and tacrolimus with methotrexate and cyclosporine for prophylaxis of acute graft-versus-host disease after marrow transplantation from unrelated donors. Blood 2000;96:2062-2068

41. Hiraoka A, Ohashi Y, Okamoto S, Moriyama Y, Nagao T, Kodera Y, Kanamaru A, Dohy H, Masaoka T; Japanese FK506 BMT (Bone Marrow Transplantation) Study Group. Phase III study comparing tacrolimus (FK506) with cyclosporine for graft-versus-host disease prophylaxis after allogeneic bone marrow transplantation. Bone Marrow Transplant 2001;28:181-185.

42. Imado T, Iwasaki T, Kuroiwa T, Sano H, Hara H. Effect of FK506 on donor T-cell functions that are responsible for graft-versus-host disease and graft-versus-leukemia effect. Transplantation 2004;77:391-398.

43. Allison AC, Almquist SJ, Muller CD, Eugui EM. In vitro immunosuppressive effects of mycophenolic acid and an ester pro-drug, RS-61443. Transplant Proc 1991;23:10-14.

44. Allison AC, Eugui EM. Purine metabolism and immunosuppressive effects of mycophenolate mofetil (MMF). Clin Transplant 1996;10:77-84.

45. Basara N, Blau WI, Romer E, Rudolphi M, Bischoff M, Kirsten D, Sanchez H, Gunzelmann S, Fauser AA. Mycophenolate mofetil for the treatment of acute and chronic GVHD in bone marrow transplant patients. Bone Marrow Transplant 1998;22:61-65.

46. Bornhauser M, Thiede C, Schuler U, Platzbecker U, Freiberg-Richter J, Helwig A, Plettig R, Rollig C, Naumann R, Kroschinsky F, Neubauer A, Ehninger G. Dose-reduced conditioning for allogeneic blood stem cell transplantation: durable engraftment without antithymocyte globulin. Bone Marrow Transplant 2000;26:119-125.

47. Kernan NA, Flomenberg N, Dupont B, O'Reilly RJ. Graft rejection in recipients of T-cell-depleted HLA-nonidentical marrow transplants for leukemia. Identification of host-derived antidonor allocytotoxic $\mathrm{T}$ lymphocytes. Transplantation 1987;43:842-847.

48. Reisner Y, Kapoor N, Kirkpatrick D, Pollack MS, Dupont B, Good RA, O'Reilly RJ. Transplantation for acute leukaemia with HLA-A and B nonidentical parental marrow cells fractionated with soybean agglutinin and sheep red blood cells. Lancet 1981;2:327-331.

49. Hale G, Cobbold S, Waldmann H. T cell depletion with CAMPATH-1 in allogeneic bone marrow transplantation. Transplantation 1988;45:753-759.

50. Maraninchi D, Gluckman E, Blaise D, Guyotat D, Rio B, Pico JL, Leblond V, Michallet M, Dreyfus F, Ifrah N. Impact of T-cell depletion on outcome of allogeneic bone-marrow transplantation for standard-risk leukaemias. Lancet 1987;2:175-178.

51. Hale G, Zhang MJ, Bunjes D, Prentice HG, Spence D, Horowitz MM, Barrett AJ, Waldmann H. Improving the outcome of bone marrow transplantation by using CD52 monoclonal antibodies to prevent graft-versus-host disease and graft rejection. Blood 1998;92:4581-4590.
52. Kottaridis PD, Milligan DW, Chopra R, Chakraverty RK, Chakrabarti S, Robinson S, Peggs K, Verfuerth S, Pettengell R, Marsh JC, Schey S, Mahendra P, Morgan GJ, Hale G, Waldmann H, de Elvira MC, Williams CD, Devereux S, Linch DC, Goldstone AH, Mackinnon S. In vivo CAMPATH-1H prevents graft-versus-host disease following nonmyeloablative stem cell transplantation. Blood 2000;96:2419-2425.

53. Kolb HJ, Schmid C, Barrett AJ, Schendel DJ. Graft-versus-leukemia reactions in allogeneic chimeras. Blood 2004;103:767-776.

54. Storb R, Prentice RL, Buckner CD, Clift RA, Appelbaum F, Deeg J, Doney K, Hansen JA, Mason M, Sanders JE, Singer J, Sullivan KM, Witherspoon RP, Thomas ED. Graft-versus-host disease and survival in patients with aplastic anemia treated by marrow grafts from HLA-identical siblings. Beneficial effect of a protective environment. N Engl J Med 1983;308:302-307.

55. Beelen DW, Haralambie E, Brandt H, Linzenmeier G, Muller KD, Quabeck K, Sayer HG, Graeven U, Mahmoud HK, Schaefer UW. Evidence that sustained growth suppression of intestinal anaerobic bacteria reduces the risk of acute graft-versus-host disease after sibling marrow transplantation. Blood 1992;80:2668-2676.

56. Beelen DW, Elmaagacli A, Muller KD, Hirche H, Schaefer UW. Influence of intestinal bacterial decontamination using metronidazole and ciprofloxacin or ciprofloxacin alone on the development of acute graft-versus-host disease after marrow transplantation in patients with hematologic malignancies: final results and long-term follow-up of an open-label prospective randomized trial. Blood 1999;93:3267-3275.

57. Hill GR, Cooke KR, Teshima T, Crawford JM, Keith JC Jr, Brinson YS, Bungard D, Ferrara JL. Interleukin-11 promotes $\mathrm{T}$ cell polarization and prevents acute graft-versus-host disease after allogeneic bone marrow transplantation. J Clin Invest 1998;102:115-123.

58. Panoskaltsis-Mortari A, Lacey DL, Vallera DA, Blazar BR. Keratinocyte growth factor administered before conditioning ameliorates graft-versus-host disease after allogeneic bone marrow transplantation in mice. Blood 1998;92:3960-3967.

59. Kuroiwa T, Kakishita E, Hamano T, Kataoka Y, Seto Y, Iwata N, Kaneda Y, Matsumoto K, Nakamura T, Ueki T, Fujimoto J, Iwasaki T. Hepatocyte growth factor ameliorates acute graft-versus-host disease and promotes hematopoietic function. J Clin Invest 2001;107:1365-1373.

60. Teshima T, Hill GR, Pan L, Brinson YS, van den Brink MR, Cooke KR, Ferrara JL. IL-11 separates graft-versus-leukemia effects from graft-versus-host disease after bone marrow transplantation. J Clin Invest 1999;104:317-325.

61. Krijanovski OI, Hill GR, Cooke KR, Teshima T, Crawford JM, Brinson YS, Ferrara JL. Keratinocyte growth factor separates graft-versus-leukemia effects from graft-versus-host disease. Blood 1999;94:825-831.

62. Imado T, Iwasaki T, Kataoka Y, Kuroiwa T, Hara H, Fujimoto J, Sano H. Hepatocyte growth factor preserves graft-versus-leukemia effect and T-cell reconstitution after marrow transplantation. Blood 2004;104:1542-1549.

63. Antin JH, Lee SJ, Neuberg D, Alyea E, Soiffer RJ, Sonis S, Ferrara JL. A phase I/II double-blind, placebo-controlled study of recombinant human interleukin-11 for mucositis and acute GVHD prevention in allogeneic stem cell transplantation. Bone Marrow Transplant 2002;29:373-377.

64. Fraser JD, Straus D, Weiss A. Signal transduction events leading to T-cell lymphokine gene expression. Immunol Today 1993;14:357-362.

65. Harding FA, McArthur JG, Gross JA, Raulet DH, Allison JP. CD28-mediated signalling co-stimulates murine $T$ cells and prevents induction of anergy in T-cell clones. Nature 1992;356:607-609. 
66. Przepiorka D, Kernan NA, Ippoliti C, Papadopoulos EB, Giralt S, Khouri I, Lu JG, Gajewski J, Durett A, Cleary K, Champlin R, Andersson BS, Light S. Daclizumab, a humanized anti-interleukin-2 receptor alpha chain antibody, for treatment of acute graft-versus-host disease. Blood 2000;95:83-89.

67. Lee SJ, Zahrieh D, Agura E, MacMillan ML, Maziarz RT, McCarthy PL Jr, Ho VT, Cutler C, Alyea EP, Antin JH, Soiffer RJ. Effect of up-front daclizumab when combined with steroids for the treatment of acute graft-versus-host disease: results of a randomized trial. Blood 2004;104:1559-1564.

68. Lenschow DJ, Zeng Y, Thistlethwaite JR, Montag A, Brady W, Gibson MG, Linsley PS, Bluestone JA. Long-term survival of xenogeneic pancreatic islet grafts induced by CTLA41g. Science 1992;257:789-792.

69. Blazar BR, Sharpe AH, Taylor PA, Panoskaltsis-Mortari A, Gray GS, Korngold R, Vallera DA. Infusion of anti-B7.1 (CD80) and anti-B7.2 (CD86) monoclonal antibodies inhibits murine graft-versus-host disease lethality in part via direct effects on CD4+ and CD8+ T cells. J Immunol 1996; 157:3250-3259.

70. Guinan EC, Boussiotis VA, Neuberg D, Brennan LL, Hirano N, Nadler LM, Gribben JG. Transplantation of anergic histoincompatible bone marrow allografts. N Engl J Med 1999;340:1704-1714.

71. Kagi D, Vignaux F, Ledermann B, Burki K, Depraetere V, Nagata S, Hengartner H, Golstein P. Fas and perforin pathways as major mechanisms of $\mathrm{T}$ cell-mediated cytotoxicity. Science 1994;265:528-530.

72. Lowin B, Hahne M, Mattmann C, Tschopp J. Cytolytic T-cell cytotoxicity is mediated through perforin and Fas lytic pathways. Nature 1994;370:650-652.

73. Miwa K, Hashimoto H, Yatomi T, Nakamura N, Nagata S, Suda $\mathrm{T}$. Therapeutic effect of an anti-Fas ligand $\mathrm{mAb}$ on lethal graft-versus-host disease. Int Immunol 1999;11:925-931.

74. Hattori K, Hirano T, Miyajima H, Yamakawa N, Tateno M, Oshimi K, Kayagaki N, Yagita H, Okumura K. Differential effects of anti-Fas ligand and anti-tumor necrosis factor alpha antibodies on acute graft-versus-host disease pathologies. Blood 1998;91:4051-4055.

75. Piguet PF, Grau GE, Allet B, Vassalli P. Tumor necrosis factor/cachectin is an effector of skin and gut lesions of the acute phase of graft-vs.-host disease. J Exp Med 1987; 166:1280-1289.

76. Herve P, Flesch M, Tiberghien P, Wijdenes J, Racadot E, Bordigoni P, Plouvier E, Stephan JL, Bourdeau H, Holler E. Phase I-II trial of a monoclonal anti-tumor necrosis factor alpha antibody for the treatment of refractory severe acute graft-versus-host disease. Blood 1992;79:3362-3368.

77. Kobbe G, Schneider P, Rohr U, Fenk R, Neumann F, Aivado M, Dietze L, Kronenwett R, Hunerliturkoglu A, Haas R. Treatment of severe steroid refractory acute graft-versus-host disease with infliximab, a chimeric human/mouse antiTNFalpha antibody. Bone Marrow Transplant 2001;28:47-49.

78. Couriel D, Saliba R, Hicks K, Ippoliti C, de Lima M, Hosing C, Khouri I, Andersson B, Gajewski J, Donato M, Anderlini P, Kontoyiannis DP, Cohen A, Martin T, Giralt S, Champlin R. Tumor necrosis factor-alpha blockade for the treatment of acute GVHD. Blood 2004;104:649-654.

79. Marty FM, Lee SJ, Fahey MM, Alyea EP, Soiffer RJ, Antin JH, Baden LR. Infliximab use in patients with severe graft-versus-host disease and other emerging risk factors of non-Candida invasive fungal infections in allogeneic hematopoietic stem cell transplant recipients: a cohort study. Blood 2003;102:2768-2776.

80. Jacobsohn DA, Hallick J, Anders V, McMillan S, Morris L, Vogelsang GB. Infliximab for steroid-refractory acute GVHD: a case series. Am J Hematol 2003;74:119-124.
81. Sullivan KM, Shulman HM, Storb R, Weiden PL, Witherspoon RP, McDonald GB, Schubert MM, Atkinson K, Thomas ED. Chronic graft-versus-host disease in 52 patients: adverse natural course and successful treatment with combination immunosuppression. Blood 1981;57:267-276.

82. Sullivan KM, Witherspoon RP, Storb R, Weiden P, Flournoy N, Dahlberg S, Deeg HJ, Sanders JE, Doney KC, Appelbaum FR. Prednisone and azathioprine compared with prednisone and placebo for treatment of chronic graft-v-host disease: prognostic influence of prolonged thrombocytopenia after allogeneic marrow transplantation. Blood 1988;72:546-554.

83. Sullivan KM, Witherspoon RP, Storb R, Deeg HJ, Dahlberg S, Sanders JE, Appelbaum FR, Doney KC, Weiden P, Anasetti C. Alternating-day cyclosporine and prednisone for treatment of high-risk chronic graft-v-host disease. Blood 1988;72:555-561.

84. Mookerjee B, Altomonte V, Vogelsang G. Salvage therapy for refractory chronic graft-versus-host disease with mycophenolate mofetil and tacrolimus. Bone Marrow Transplant 1999;24:517-520.

85. Gilman AL, Chan KW, Mogul A, Morris C, Goldman FD, Boyer M, Cirenza E, Mazumder A, Gehan E, Cahill R, Frankel S, Schultz K. Hydroxychloroquine for the treatment of chronic graft-versus-host disease. Biol Blood Marrow Transplant 2000;6:327-334.

86. Goldberg JD, Jacobsohn DA, Margolis J, Chen AR, Anders V, Phelps M, Vogelsang GB. Pentostatin for the treatment of chronic graft-versus-host disease in children. J Pediatr Hematol Oncol 2003;25:584-588.

87. Alcindor T, Gorgun G, Miller KB, Roberts TF, Sprague K, Schenkein DP, Foss FM. Immunomodulatory effects of extracorporeal photochemotherapy in patients with extensive chronic graft-versus-host disease. Blood 2001;98:1622-1625.

88. Nakamura T, Nawa K, Ichihara A. Partial purification and characterization of hepatocyte growth factor from serum of hepatectomized rats. Biochem Biophys Res Commun 1984;122:1450-1459.

89. Nakamura T, Nishizawa T, Hagiya M, Seki T, Shimonishi M, Sugimura A, Tashiro K, Shimizu S. Molecular cloning and expression of human hepatocyte growth factor. Nature 1989;342:440-443.

90. Kawaida K, Matsumoto K, Shimazu H, Nakamura T. Hepatocyte growth factor prevents acute renal failure and accelerates renal regeneration in mice. Proc Natl Acad Sci USA 1994;91:4357-4361.

91. Ohmichi H, Matsumoto K, Nakamura T. In vivo mitogenic action of HGF on lung epithelial cells: pulmotrophic role in lung regeneration. Am J Physiol 1996;270:L1031-L1039.

92. Kato Y, Yu D, Lukish JR, Schwartz MZ. Influence of luminal hepatocyte growth factor on small intestine mucosa in vivo. J Surg Res 1997;71:49-53.

93. Matsuda Y, Matsumoto K, Ichida T, Nakamura T. Hepatocyte growth factor suppresses the onset of liver cirrhosis and abrogates lethal hepatic dysfunction in rats. J Biochem 1955;118:643-649.

94. Okamoto T, Takatsuka H, Fujimori Y, Wada H, Iwasaki T, Kakishita E. Increased hepatocyte growth factor in serum in acute graft-versus-host disease. Bone Marrow Transplant 2001;28:197-200.

95. Via CS, Rus V, Gately MK, Finkelman FD. IL-12 stimulates the development of acute graft-versus-host disease in mice that normally would develop chronic, autoimmune graft-versus-host disease. J Immunol 1994;153:4040-4047.

96. Okamoto I, Kohno K, Tanimoto T, Iwaki K, Ishihara T, Akamatsu S, Ikegami H, Kurimoto M. IL-18 prevents the development of chronic graft-versus-host disease in mice. J Immunol 2000;164:6067-6074.

97. Weiden PL, Sullivan KM, Flournoy N, Storb R, Thomas ED. Antileukemic effect of chronic graft-versus-host disease: contribution to improved survival after allogeneic marrow transplantation. N Engl J Med 1981;304:1529-1533. 
98. Koh MB, Prentice HG, Lowdell MW. Selective removal of alloreactive cells from haematopoietic stem cell grafts: graft engineering for GVHD prophylaxis. Bone Marrow Transplant 1999;23:1071-1079.

99. Molldrem JJ, Lee PP, Wang C, Felio K, Kantarjian HM, Champlin RE, Davis MM. Evidence that specific T lymphocytes may participate in the elimination of chronic myelogenous leukemia. Nature Med 2000;6:1018-1023.

100. Bonini C, Ferrari G, Verzeletti S, Servida P, Zappone E, Ruggieri L, Ponzoni M, Rossini S, Mavilio F, Traversari C, Bordignon C. HSV-TK gene transfer into donor lymphocytes for control of allogeneic graft-versus-leukemia. Science 1997;276:1719-1724.

101. Murphy WJ, Blazar BR. New strategies for preventing graft-versus-host disease. Curr Opin Immunol 1999;11:509-515. 